\title{
A Review of Factors Affecting Anthocyanin Bioavailability: Possible Implications for the Inter-Individual Variability
}

\author{
Merve Eda Eker ${ }^{1,2}$, Kjersti Aaby ${ }^{3}{ }^{\circledR}$, Irena Budic-Leto ${ }^{4}$, Suzana Rimac Brnčić ${ }^{5}$, Sedef Nehir El ${ }^{2}$, \\ Sibel Karakaya ${ }^{2}$, Sebnem Simsek ${ }^{2}$, Claudine Manach ${ }^{6}$, Wieslaw Wiczkowski ${ }^{7}$ (D) and \\ Sonia de Pascual-Teresa ${ }^{1, *(D)}$ \\ 1 Department of Metabolism and Nutrition, Institute of Food Science, Technology and \\ Nutrition (ICTAN-CSIC), Jose Antonio Novais 10, 28040 Madrid, Spain; merveedaeker@gmail.com \\ 2 Department of Food Engineering, Ege University, Izmir 35100, Turkey; sedef.el@ege.edu.tr (S.N.E.); \\ sibel.karakaya@ege.edu.tr (S.K.); sebnem.simsek@ege.edu.tr (S.S.) \\ 3 Nofima, Norwegian Institute of Food, Fisheries and Aquaculture Research, N-1430 Ås, Norway; \\ Kjersti.Aaby@Nofima.no \\ 4 Institute for Adriatic Crops and Karst Reclamation, Put Duilova 11, 21000 Split, Croatia; \\ Irena.Budic-Leto@krs.hr \\ 5 Faculty of food Technology and Biotechnology, University of Zagreb, Pierottijeva 6, 10000 Zagreb, Croatia; \\ srimacbrncic@pbf.hr \\ 6 INRA, Université Clermont-Auvergne, Human Nutrition Unit, CRNH Auvergne, F-63000 Clermont-Ferrand, \\ France; claudine.manach@inra.fr \\ 7 Institute of Animal Reproduction and Food Research. Polish Academy of Sciences, 10-748 Olsztyn, Poland; \\ w.wiczkowski@pan.olsztyn.pl \\ * Correspondence: s.depascualteresa@csic.es; Tel.: +34-91-5492300 (ext. 231309)
}

Received: 22 November 2019; Accepted: 15 December 2019; Published: 18 December 2019

\begin{abstract}
Anthocyanins are dietary bioactive compounds showing a range of beneficial effects against cardiovascular, neurological, and eye conditions. However, there is, as for other bioactive compounds in food, a high inter and intra-individual variation in the response to anthocyanin intake that in many cases leads to contradictory results in human trials. This variability could be caused at two levels, one at the bioavailability level and the other at the effect and mechanisms of action. In this context, we have thoroughly reviewed the scientific literature on anthocyanins variability caused by variation in bioavailability. Based on the literature reviewed, we have concluded that the variability in anthocyanins bioavailability might be produced by the lack of homogeneity introduced at three different levels: food matrix and food processing, enzymes involved in anthocyanin metabolism and transport, and anthocyanin metabolizing gut microbiota. However, it should be noted that the literature on anthocyanins bioavailability considering inter or intra-individual variability is still very scarce, which makes it difficult to reach any firm conclusion on the main metabolizing enzymes or bacteria that would be responsible for the variability in anthocyanin bioavailability.
\end{abstract}

Keywords: anthocyanin; variability; bioavailability; food processing; metabolism; microbiota

\section{Introduction}

Anthocyanins receive attention and are studied both because of their impact on food sensory properties, being responsible for the red-blue color of berries, fruits, and certain vegetables-based products, and because of their health-promoting properties [1-5].

Anthocyanins and anthocyanin-rich foods have been shown to display several biological activities which may have positive implications on human health, including anti-inflammatory, anti-diabetic, 
and antioxidant activities [2,3]. Especially important is their role in preventing cardiovascular health disease through modulation of risk factors such as blood pressure, platelet aggregation, and vascular function $[1,5,6]$. Furthermore, the intake of anthocyanins seems to have promising effect on cognitive function in humans, with both acute and long-term intakes [4]. Besides, no negative effect of anthocyanin derivatives has been reported, even after ingestion of very high doses [7].

However, the effectiveness of anthocyanins in protecting consumers against chronic diseases depends on numerous factors, which, among others, are influenced by their bioavailability, that is, absorption, metabolism, distribution, and excretion (ADME). Ingested anthocyanins may be efficacious for one individual, but may not trigger the same effect for another. This variability in response to anthocyanins may be due to an inter-individual variation in the absorption and metabolism of these substances or might also be due to a variability on their intrinsic effect to target genes or proteins. An important role in this variability may be ascribed to intrinsic aspects such as genetics, age, sex, and physiological or pathological states. Genetic variation for enzymes involved in the absorption and metabolism of anthocyanins may result in large differences in the expression of a functional enzyme. The mentioned aspects are part of a phenomenon known as inter-individual variability in response to bioactive compounds.

Differences in a person's gut microbiota and metabolizing enzymes will influence ADME of anthocyanins and consequently, their bioactivity and exerted health effects. It is also important to note that the chemical form of anthocyanins and the food matrix in which these pigments are dispersed in combination with individual physiological variability may be critical factors determining anthocyanin bioavailability.

Consequently, the same dietary intake of anthocyanins can result in different concentration absorbed and different metabolites and consequently, different health effects. In fact, this could be the reason for conflicting or contradictory results of clinical studies on effects of anthocyanins. The aim of this paper is to thoroughly review previous work on anthocyanins bioavailability, in order to assess inter-individual variation in anthocyanins bioaccessibility in humans and to evaluate how it is influenced by food processing, the variability in the enzymes involved, and human gut microbiota composition.

\section{Methodology}

A systematic literature review was undertaken to better understand anthocyanin metabolism and inter-individual variability after anthocyanin intake. Databases (Web of Science and PubMed) were searched for articles written in English and published between January 2000 and August 2018. Keywords used for the bibliographical search were [anthocyanin OR cyanidin OR pelargonidin OR delphinidin OR peonidin OR petunidin OR malvidin] AND [bioavailability OR absorption OR metabolism OR urinary excretion OR plasma OR urine OR pharmacokinetic OR conjugated OR glucuronide OR sulfat* OR sulphat* OR methylat* OR gut OR colon] AND [volunteer OR in vivo OR intervention OR human]. As a result of these searches, we found 1319 papers in the Web of Science and 1426 papers in PubMed databases. Papers found irrelevant for our objective, duplicated papers, or conflicting ones were excluded from the study. After the elimination, we obtained 86 papers that were in accordance with the aim of this work, that is, influence of the type of food processing, the variability in the enzymes involved in anthocyanin metabolism, and human gut microbiota composition on anthocyanin bioavailability. However, only four of these papers dealt with inter-individual variability of anthocyanins bioavailability.

\section{Anthocyanin Structure and Distribution}

Anthocyanins are water-soluble pigments belonging to the flavonoid group of polyphenols [8,9]. They have glycosidic structure, that is, one or more sugar molecules (glucose, galactose, rhamnose, xylose, or arabinose) bound to the aglycon, the anthocyanidin. The sugar can be acylated with aliphatic acids (malonic, succinic, malic, and acetic acid) or cinnamic acids (p-coumaric, ferulic, and sinapic 
acid) $[8,9]$. Anthocyanins differ in (i) the position and number of hydroxyl groups, (ii) the degree of methylation of hydroxyl groups, (iii) the nature and number of sugar molecules attached to the aglycone, and (iv) and aliphatic or aromatic acids attached to the sugar molecule [8]. In nature, more than 600 individual anthocyanins and more than 30 anthocyanidins have been identified [2,9], but only six aglycones are common and widely distributed in foods: pelargonidin, cyanidin, peonidin, delphinidin, petunidin, and malvidin (Figure 1). Most of the anthocyanins in foods are cyanidin derivatives, followed by delphinidin and pelargonidin and the three methylated anthocyanins, peonidin, malvidin, and petunidin [9]. Cyanidin-3-glucoside is the most widely distributed anthocyanin in edible plants and consequently, is the most studied compound [10-12].<smiles></smiles>

\begin{tabular}{lll}
\hline R1 & R2 & Anthocyanidin \\
\hline $\mathrm{H}$ & $\mathrm{H}$ & Pelargonidin \\
$\mathrm{OH}$ & $\mathrm{H}$ & Cyanidin \\
$\mathrm{OH}$ & $\mathrm{OH}$ & Delphinidin \\
$\mathrm{OH}$ & $\mathrm{OCH} 3$ & Petunidin \\
$\mathrm{OCH} 3$ & $\mathrm{H}$ & Peonidin \\
$\mathrm{OCH} 3$ & $\mathrm{OCH} 3$ & Malvidin \\
\hline
\end{tabular}

Figure 1. Anthocyanidin structure.

The main dietary sources of anthocyanins are pigmented fruits and vegetables such as berries, grapes, pomegranates, eggplant, and red cabbage and products derived of these commodities, for example, juices and red wines $[7,10]$. The daily intake of anthocyanins is estimated to be $12.5 \mathrm{mg}$ per person in the United States [10], however, anthocyanin intake shows a huge variability between individuals due to their content being restricted to a few food items. In this sense, a recent cohort study showed values for anthocyanin intake to be below $9.2 \mathrm{mg} / \mathrm{d}$ in the first quintile to more than $23.2 \mathrm{mg} / \mathrm{d}$ in the higher quintile [13].

\section{Effects of Food Processing and Food Matrix}

Food processing influences both content and bioaccessibility of anthocyanins. The bioaccessibility of anthocyanins is dependent on the food matrix, on other food components like alcohol and fat, as well as on the structure of the anthocyanin [14]. Acylation increases anthocyanin stability and substantially declines bioavailability $[15,16]$. Anthocyanidin structure is a determinant of bioavailability, with pelargonidin-based anthocyanins ( 3 '-hydroxyanthocyanins) being more readily absorbed than anthocyanins with more substituents on the B-ring [17]. Structure of the anthocyanidin backbone, the presence or lack of glycosylation and hydroxylation of the basic flavylium structure, and the number, type, and acylation of bounded sugar molecules are linked to plant species and imply characteristic anthocyanins' patterns. Therefore, the plant species and food matrix are very significant factors that determine the content and bioaccessibility, and thus the bioavailability of anthocyanins. Anthocyanin bioavailability might also be modified by food $\mathrm{pH}$ and temperature [14]. Moreover, the 
presence of other constituents, which were formed and/or added within technological processes, liable to bind, solubilize, or stabilize anthocyanins could modify the bioavailability of the anthocyanins. Food processing, including home food preparation practices, is one of the main factors determining anthocyanins stability and interaction with the food matrix. Several previous studies discuss the effect of plant species, food processing, and food matrix on anthocyanins content. However, knowledge about the impact of the above factors on anthocyanins bioavailability is limited. A summary of studies exploring the effect of thermal and nonthermal processing conditions on anthocyanins content and bioaccessibility and bioavailability are presented in Table 1 . In general, thermal processing results in a decrease of anthocyanin contents and an increase of anthocyanins bioaccessibility and bioavailability. Thermal treatments damage cell walls, liberating the cytoplasmic content and making the anthocyanins more accessible for absorption $[18,19]$.

Table 1. Effect of technology and processing conditions on bioaccessibility and bioavailability of anthocyanins.

\begin{tabular}{|c|c|c|c|c|}
\hline $\begin{array}{c}\text { Technology and } \\
\text { Processing Conditions }\end{array}$ & Food & Retention & $\begin{array}{c}\text { Effect on } \\
\text { Bioaccessibility/ } \\
\text { Bioavailability }\end{array}$ & Reference \\
\hline $\begin{array}{l}\text { Microwave cooking } \\
(900 \mathrm{~W}, 12-20 \mathrm{~min})\end{array}$ & $\begin{array}{l}\text { Purple carrots (Daucus } \\
\text { carota) }\end{array}$ & $\downarrow(23 \%$ total ACs $)$ & $\begin{array}{c}\downarrow 11 \text {-14-fold } \downarrow \text { ACs } \\
\text { urine and 8-10-fold } \mathrm{d} \downarrow \\
\text { ACs in plasma }\end{array}$ & [20] \\
\hline $\begin{array}{l}\text { Conservation, jam, } \\
\text { squeeze }\end{array}$ & $\begin{array}{l}\text { Blackcurrant fruits and } \\
\text { products }\end{array}$ & $\downarrow(0.05-10.3 \%)$ & $\begin{array}{l}\downarrow \text { urine (fruit, } 0.053 \% \text {; } \\
\text { drink, } 0.036 \text { ) }\end{array}$ & [21] \\
\hline Steam-blanching (3 min) & $\begin{array}{l}\text { Blueberry puree } \\
\text { (Vaccinium } \\
\text { corymbosum) }\end{array}$ & $\uparrow \mathrm{ACs} *$ & (2. & [22] \\
\hline $\begin{array}{l}\text { Juice processing (milling, } \\
\text { mashing, pressing, } \\
\text { pasteurization) }\end{array}$ & $\begin{array}{l}\text { Black mulberries } \\
\text { Grape/blue berry }\end{array}$ & $\uparrow(213.8 \%)$ & $\downarrow$ & {$[23,24]$} \\
\hline $\begin{array}{c}\text { Fermentation (at } 18-24^{\circ} \mathrm{C} \text {, } \\
\text { pH } 3.80,14 \text { days) }\end{array}$ & $\begin{array}{c}\text { Red cabbage (Brassica } \\
\text { oleracea) }\end{array}$ & $\downarrow(15 \%)$ & $\downarrow$ & [25] \\
\hline $\begin{array}{c}\text { Domestic cooking } \\
\left(45 \mathrm{~s}-2.5 \mathrm{~min} \text {, at } 250^{\circ} \mathrm{C}\right)\end{array}$ & $\begin{array}{l}\text { ACs enriched food } \\
\text { matrices (milkshake, } \\
\text { custard dessert, } \\
\text { pancake, and } \\
\text { omellette) }\end{array}$ & Very high recovery & $\approx$ & [26] \\
\hline
\end{tabular}

Several in vitro and in vivo studies have reported both positive and negative effects of other co-ingested food components on anthocyanins bioaccessibility [20-26] (Table 1). These contradictory results may be due to differences in the type of anthocyanin, the degree and type of food processing, including exposure to different $\mathrm{pH}$, temperature, light conditions, and the presence of metal ions or oxygen [27]. A study with hyperlipidemic rabbits reported a higher anthocyanin absorption rate from blackcurrant juice versus an aqueous citric acid solution of purified anthocyanins, suggesting a possible increase in bioavailability resulting from the inclusion of the anthocyanin in a food matrix [28]. On the other hand, in humans, the anthocyanin peak plasma concentration was delayed with co-ingestion of blackcurrant juice with rice cake, whereas no effect was observed for total absorption or excretion of anthocyanins. The results of the study indicated that the rice cake prolonged the stay in the stomach with a slower uptake of anthocyanins from the intestine [28]. A study in humans with consumption of strawberries with or without cream showed no significant difference in plasma and urinary excretion between groups, however, the time required to reach the maximum serum level was delayed in subjects consuming strawberries with cream, suggesting the slowing effect of fat on anthocyanins gastric transit [29]. Additionally, it has been reported that the in vivo antioxidant activity of dark chocolate is reduced by either the effect of milk during intake or the manufacturing process, due to the possible interaction between flavonoids and milk proteins [30]. Additionally, in a human trial, 
Wiczkowski et al. [25] showed that bioavailability of anthocyanins from fresh red cabbage was higher when compared with fermented red cabbage. The results obtained by Kurilich et al. [20] indicated that the bioavailability of carrot anthocyanins was unaffected by cooking, although cooking increased relative urinary recoveries of nonacylated anthocyanins, but not of acylated anthocyanins.

Also, a few bioavailability studies have investigated the effects of meal composition and other constituents on anthocyanin absorption. Bub et al. [31] suggested that higher glucose content in food products could delay anthocyanins absorption, which could result from competitive action of glucose and anthocyanin on the sodium-dependent glucose cotransporter SGLT1. In another study, Mulleder et al. [32] compared the urinary excretion of anthocyanins when elderberry concentrates were consumed with and without sucrose and showed that urinary recovery of anthocyanins was lower after sucrose consumption. Moreover, the consumption of elderberry juice with sucrose resulted in delaying anthocyanin excretion. A similar phenomenon was found by Walton et al. [33], who in an experiment with pigs showed that that co-consumption of other foods delayed the absorption of anthocyanins from blackcurrant but did not influence the maximum plasma concentration (Cmax) and area under the curve (AUC) values.

Regarding alcohol, results are also controversial. While Bub et al. [31] showed that bioavailability of malvidin-3-glucoside was not significantly different after the consumption of either red wine or dealcoholized red wine in absolute terms, they found that alcohol was able to speed up the absorption ( $\operatorname{tmax}=50 \mathrm{~min}$ for wine and $90 \mathrm{~min}$ for dealcoholized red wine). However, Frank et al. [34] did not find that the bioavailability of anthocyanins was significantly affected by alcohol consumption.

McDougall et al. [35] studied the bioavailability of raspberry anthocyanins using an in vitro digestion system, showing that anthocyanins were stable to gastric conditions, whereas they were poorly recovered following pancreatic digestion and that the bioavailability was not affected by joint consumption with different complex food products. Similarly, Sengul et al. [36], using an in vitro gastrointestinal digestion model to study the bioaccessibility of pomegranate anthocyanins, reported that $89 \%$ of anthocyanins were stable in gastric conditions, whereas this ratio was just $38 \%$ after pancreatic digestion, and only $12 \%$ was available in the serum. Among the studied foodstuffs, only meat, soymilk, and cream co-digestion resulted in a loss in serum anthocyanin levels. They concluded that proteins decreased and carbohydrates and fatty acids increased the total anthocyanins content in serum.

Conversely, Ribnicky et al. [37], when investigating the effects of different digestive conditions on the bioaccessibility of blueberry anthocyanins using the Netherlands Organisation for applied scientific research (TNO) gastrointestinal model (TIM-1), concluded that the lipid-rich matrices did not affect anthocyanin bioavailability, whereas protein-rich matrices protected anthocyanins during transit through the upper digestive tract.

Again, in an in vitro gastrointestinal digestion model, Pineda-Vadillo et al. [26] concluded that anthocyanins remain stable and soluble during the oral and gastric steps of digestion, whereas many of them are extensively modified or insolubilized during the intestinal step of digestion. Both thermal degradation and fat and protein interactions decreased anthocyanin bioavailability in this study. Regarding other food components, docosahexaenoic acid (DHA) significantly decreased the bioaccessibility of anthocyanins [38].

\section{Effect of Enzymatic Variability}

After consumption, a very low proportion $(<2 \%)$ of the original anthocyanins are retrieved in the circulation (plasma/urine) [39]. However, we now know that after ingestion, anthocyanins are subjected to $\mathrm{pH}$-dependent transformations and are hydrolyzed by several enzymes in the small intestine [40]. The released aglycon can enter the epithelial cells by passive diffusion, or a sodium-dependent glucose transporter (SGLT-1) can be involved in the transport of the glycosides (anthocyanins). A portion of the ingested anthocyanin reaches the large intestine, where they are metabolized by the gut microbiota to a range of low-molecular-weight catabolites (phenolic acids and other phenols), which are excreted 
in the feces or absorbed again. Once absorbed, the anthocyanins and their catabolites undergo phase 2 enzymatic metabolism, first in the wall of the intestine, then are further converted in the liver, that is, the compounds formed are glucuronidated, sulphated, and methylated, catalyzed by UDP-glucuronosyltransferases (UGTs), sulphotransferases (SULTs), and catechol-O-methyltransferases (COMT), respectively. Anthocyanins present the particularity, when compared with other flavonoids, of being absorbed in their native form, as glycosides [41].

Conjugation reactions, particularly sulfation, glucuronidation, and methylation, are known to be involved in the metabolism of phenolic compounds in the human body, generally resulting in stabilization and increased water solubility, and therefore, modifying their distribution and excretion. Sulfation of phenolic compounds is mediated by cytosolic sulfotransferases (SULTs). SULTs catalyze the transfer of a sulfonate group from 3-phosphoadenosine-5-phosphosulfate to a substrate containing a hydroxyl group. The isoforms SULT1A1, SULT1A3/4, SULT1B1, SULT1E1, and SULT2A1 are considered the most relevant in polyphenol metabolism in human adults. Methylation catalyzed by COMT is another metabolic pathway of phenolic compounds [42]. Protocatechuic acid-O-sulfate, vanillic acid-4-O-sulfate, and ferulic acid-4-O-sulfate were plasma metabolites of 13C-labelled cyanidin-3-glucoside [43].

Glucuronidation of phenolic compounds is mediated by the uridine diphosphate (UDP)-glucuronosyltransferases. Glucuronidation is a major metabolic pathway that promotes the elimination of drugs and other potentially toxic exogenous and endogenous compounds, and the existence of inter-individual variability in drug glucuronidation leading to ineffective drug levels or drug toxicity has been reported (Table 2). The individual UGT isoforms expressed in the human liver and ranked from most to least abundant are UGTs 1A1, 1A3, 1A6, 1A9, 2B4, 2B7, 2B10, 2B15, and 2B17. Also, variability in UGT activities has been reported. Possible factors influencing UGT activity variability have been reported as age, sex, genetic polymorphism, and enzyme inducers. Several reviews reported the ontogeny of hepatic drug glucuronidation [44,45]. According to these reviews, prior to, and immediately following, birth, the liver appears to have limited ability to glucuronidate drugs. In initial studies, it was shown that fetal human livers had very low ability to glucuronidate phenolic substrates, which are glucuronidated by UGT1A [46]. Strassburg et al. [47], studied UGT expression in fetal, pediatric (6-24 month), and adult human livers, showing that none of the UGTs were detected in fetal human liver. In contrast, all UGTs expressed in adult liver were determined in pediatrics by 9 months of age. Bolling et al. [48] concluded in a study done in rat liver microsomes from male F344 that the capacity for flavonoid glucuronidation by rat liver microsomes was dependent on age, UGT isoenzymes, and flavonoid structure. Old age appears to have a minimal effect on UGT function.

Several UGTs including UGT2B15 and UGT1A6 have been shown to display higher activities in males than in females. Buckley and Klaassen [49] investigated the tissue- and gender-specific mRNA expression patterns of mouse UGT. They observed that UGT1A1, 1A2, 1A5, and 1A10 and UGT2B1, UGT2B5/37/38 are significantly different between male and female mice in liver and kidney. However, UGT1A7, 1A8, and 1A10, which play a key role in the conjugation and detoxification of numerous phenolic compounds, did not show gender-specific differences. Based on these results we can say that UGT activities depend on tissue, gender, and type of UGT.

Enzyme inducers, including coadministered drugs, smoking, and alcohol, may increase hepatic UGT levels [46]. Hollands et al. [21] investigated urinary excretion of strawberry anthocyanins, which are mainly pelargonidin-3-glucoside. The main metabolite identified in the urine samples was a pelargonidin-monoglucuronide. Although the dose excretion curve was linear for all individuals, there was individual variation in urinary anthocyanin yields, probably due to differences in UGT levels or activity. An effect of diet on UGT1A enzyme activity, as measured by serum bilirubin, has been shown. An increase in UGT1A enzyme activity has been reported for vegetable-containing diets, proving that dietary habits may modulate enzyme activity so that phenolic compounds ADME can be affected [50]. 
Table 2. Enzymes or enzyme families participating in anthocyanin metabolism that have shown variability at different levels.

\begin{tabular}{|c|c|c|c|c|}
\hline Enzyme (or Family) & Isoforms & Metabolites & Variability & Reference \\
\hline \multirow[t]{2}{*}{ Beta-glucosidases } & $\begin{array}{l}\text { LPH, cytosolic } \\
\beta \text {-glucosidase }\end{array}$ & $\begin{array}{l}\text { Glucuronides, } \\
\text { sulfates }\end{array}$ & Small intestine & [51] \\
\hline & $\begin{array}{l}\text { GBA1, GBA2, GBA3-1, } \\
\text { GBA3-2 }\end{array}$ & Aglycons & Microbiota & [52] \\
\hline Sulphotransferases (SULT) & $\begin{array}{l}\text { SULT1A1, SULT1A3/4, } \\
\text { SULT1B1, SULT1E1 } \\
\text { and SULT2A1 }\end{array}$ & Sulphates & Tissue & [53] \\
\hline $\begin{array}{c}\text { Uridine diphosphate } \\
\text { (UDP)-glucuronosyltransferases } \\
\text { (UGT) }\end{array}$ & $\begin{array}{l}\text { UGT1A, UGT2A, } \\
\text { UGT2B, UGT3, or } \\
\text { UGT8 families }\end{array}$ & Glucuronates & Age, smoking & [48] \\
\hline \multirow{3}{*}{$\begin{array}{l}\text { Catechol-O-methyltransferases } \\
\text { (COMTs) }\end{array}$} & $\begin{array}{l}\text { UGT1A1, UGT1A2, } \\
\text { UGT 1A5, UGT1A6 }\end{array}$ & Glucuronates & Sex, tissue & [49] \\
\hline & MB-COMT, S-COMT & $\begin{array}{l}\text { Methyl } \\
\text { substitution }\end{array}$ & Addictions & [54] \\
\hline & $\begin{array}{l}\text { AA genotype, GG } \\
\text { genotype }\end{array}$ & $\begin{array}{l}\text { Methyl } \\
\text { substitution }\end{array}$ & Genetic & [55] \\
\hline
\end{tabular}

Mallery et al. [52] studied patient-specific differences in local retention and metabolism of freeze-dried black raspberries' components in oral cavities of 10 healthy individuals and investigated metabolic profiling of the enzymes in tissues obtained from 15 donors. They proposed that as the mouth is contiguous with the more distal components of the gastrointestinal tract, oral cavity enteric recycling is logical and plausible. They reported that oral microflora, salivary enzymes, and surface of oral epithelium contributed to intraoral bioactivation of anthocyanins via $\beta$-glucosidase activity. High levels of inter-donor differences in $\beta$-glucosidase activities were observed. Phase II enzymes including UGTs, COMT, UDP-glucose-dehydrogenase (UDP-Glu-DH), breast cancer resistance protein (BCRP), and $\beta$-glucosidase in 15 tissues were determined. Fourteen out of 15 tissues contained sodium-dependent SGLT1. Another important finding was the detection of protocatechuic acid glucuronide in post-rinse saliva. Inter-donor differences in salivary anthocyanin levels were also apparent. The greatest inter-donor variability was noted at the early $(0,5$, and $30 \mathrm{~min})$ time points, and most apparent in cyanidin-3-rutinoside (predominant BRB anthocyanin) and protocatechuic acid (stabilized metabolite). Average inter-donor differences at early time points were 5-fold, with ranges from 3.6- to 10.3-fold.

Riches et al. [53] studied different SULT enzymes (SULT1A1, SULT1A3/4, SULT1B1, SULT1E1, and SULT2A1) which were obtained from human adult's liver, small intestine, kidney, and lung. They detected the five major SULTs in human liver, small intestine, kidney, and lung cytosol and showed variation between individuals and tissues. There was great variation between individuals in SULT in liver, that is, SULT1A1, SULT1B1, SULT1E1, and SULT2A1. Inter-individual variability of SULTA1 attributed to coding region single nucleotide polymorphism and gene copy number polymorphism. SULT1B1 and SULT1A3 are two of the most dominant SULT in gastrointestinal tract tissues, and then SULT1A1, SULT1E1, and SULT2A1, respectively. In kidney, SULT1A1, SULT1B1, SULT1A3, and SULT2A1, at very low levels, have been detected, but not SULT1E1. Conversely, in lung, SULT1E1 showed the higher levels, followed by SULT1A1, SULT1A3, SULT1B1, and SULT2A1. In conclusion, it was shown that the small intestine has the highest total expression levels of SULT, followed by the liver, kidney, and lung, respectively. Strong variations were shown between individuals and tissues. However, no gender-specific or age-specific variations were shown in the SULT liver expression levels.

COMT is ubiquitously present in mammals and catalyzes the O-methylation of a wide variety of endogenous and exogenous catecholic substrates using S-adenosyl-L-methionine as the methyl donor. The human COMT exists in a soluble form (S-COMT) and a membrane-bound form (MB-COMT). Bai et al. [54] showed that when the flavonoid catechin was used as substrate, the formation of 3'-O-methylation products was favored over the 4'-O-methylated products and that MB-COMT had higher binding affinity for 3-O-methylation than S-COMT. Two COMT genotypes have been 
described, GG and AA. It has been shown that individuals having the GG COMT genotype had higher urinary methylated epigallocatechin concentrations after consuming tea than those with AA COMT [55]. Besides these enzymes (SULT, UGT, COMT, etc.), Fernandes et al. [45] indicated that brush border membrane enzymes like lactase phloridzin hydrolase (LPH) may participate in hydrolyzation of anthocyanins and may induce an increase in anthocyanin bioavailability. Németh et al. [51] demonstrated that LPH and cytosolic $\beta$-glucosidase can hydrolyze different types of flavonoids glycosides, which suggests a possible hydrolysis of anthocyanins by LPH and cytosolic $\beta$-glucosidase. Additionally, they observed significant variability in activity of $\beta$-glucosidase isolated from different human small intestine samples. These results may serve as a base to better understand the possible effect of enzymatic variations on the inter-individual variations encountered in anthocyanin's ADME.

\section{Effect of the Microbiota on Inter-Individual Variability of Anthocyanin Bioavailability}

Among the factors that might affect the inter-individual variation of anthocyanins bioavailability, the microbiota composition has emerged as one of the most important and less well known. In the last fifteen years or so, the number of research papers regarding the microbiota effect on different pathological or physiological conditions has increased in an exponential way. Microbiota catabolism leads to production of new anthocyanin metabolites in the human gut. These metabolites may be absorbed by the colon epithelium and induce modulation of the microbiota composition. The bioavailability of anthocyanins depends on gut microflora and their biotransformation mechanisms. Gut microbiota vary on a person-to-person basis and in this sense, an inter-individual variability in anthocyanin ADME could be expected. In general, it is now assumed that if anthocyanins have a beneficial effect on human health, this effect is mediated by what is called breakdown metabolites, formed by the different bacteria existing in the microbiota. However, when searching in electronic databases (Medline PubMed and Web of Science) for anthocyanins and microbiota, less than 200 articles were initially selected. After removal of duplicates and an initial screening, 43 articles were selected for further reading. After detailed analysis of the full text, 12 articles were rejected, due to lack of relevant outcomes, aspects of the study design, and so forth. Finally, articles published between 2005 and 2018 were incorporated in this review (see Tables 3-5). Other articles were not selected because, for example, the polyphenol composition of the dietary sources of anthocyanins was too complex or because anthocyanins did not represent a big proportion with respect to the total polyphenol content (i.e., grape juice or red wine extract), although they suggested a role of the human intestinal microbiota on anthocyanins metabolism [56,57].

After raspberry consumption, a large number of polyphenol metabolites were quantified in human urine by Ludwig et al. [58], including the ones already described and others including methyl-, glycine-, glucuronide-, and sulfate derivatives of phenolic acids and phenylpropanoids. Very interestingly, Ludwig et al. [58] showed that due to the early appearance of $4^{\prime}$-hydroxyhippuric acid and ferulic acid derivatives in plasma, these metabolites may be absorbed, maybe after degradation in the upper gastrointestinal tract, without any microflora intervention on their metabolism.

Another reason for not including some papers in the table is the use of food extracts or food products in which anthocyanins do not represent the main source of polyphenols and from which the formation of metabolites cannot be confirmed. One example is the study of Burgos-Edwards et al. [59], in which a number of metabolites, including 3-coumaroylquinic acid, feruloylquinic acid, quercetin-3-rutinoside, or vitexin, were found after fermentation with human feces of a red Chilean currant. However, these compounds are very unlikely anthocyanin metabolites, and it is difficult to conclude about which polyphenol they are derived from. 
Table 3. Microbial metabolites of anthocyanins and bacteria regulated by anthocyanins.

\begin{tabular}{|c|c|c|c|c|c|c|}
\hline Species & Anthocyanins & Model & Metabolites Found & Bacterial Species & Ef & Reference \\
\hline Bac & $\begin{array}{c}\text { C3G } \\
\text { (blackcurrant) }\end{array}$ & in vitro & $\begin{array}{l}\text { 3,4-dihydroxybenzoic acid, } \\
\text { 2,4,6-trihydroxybenzaldehyde }\end{array}$ & $\begin{array}{l}\text { Clostridium saccharogumia } \\
\text { Eubacterium ramulus }\end{array}$ & & [60] \\
\hline Bac & $\begin{array}{l}\text { C3G, C3R } \\
\text { (mulberry) }\end{array}$ & in vitro & $\begin{array}{l}\text { caffeic acid, ferulic acid, } \\
\text { protocatechuic acid, chlorogenic } \\
\text { acid, cryptochlorogenic acid, }\end{array}$ & $\begin{array}{l}\text { Lactobacillus plantarum, } \\
\text { Streptococcus thermophiles }\end{array}$ & $\uparrow$ & [61] \\
\hline Bac & $\begin{array}{c}\mathrm{C} 3 \mathrm{G} \\
\text { (black rice) }\end{array}$ & in vitro & $\begin{array}{l}\text { phenyllactic acid, benzoic acid, } \\
\text { phenylacetic acid, } \\
\text { 2,4,6-trihydroxybenzoic, } \\
\text { 4-hydroxyphenylethanol, } \\
\text { 4-hydroxybenzoic acid, } \\
\text { 4-hydroxyphenylacetic acid, } \\
\text { 3-methoxy-4-hydroxybenzoic acid }\end{array}$ & $\begin{array}{l}\text { Bifidobacteria } \\
\text { Lactobacilli }\end{array}$ & $\uparrow$ & [62] \\
\hline Bac & $\begin{array}{l}\text { Pn deriv (purple } \\
\text { sweet potato) }\end{array}$ & in vitro & & $\begin{array}{l}\text { Bifidobacterium bifidum } \\
\text { B. adolescentis } \\
\text { B. infantis } \\
\text { L. acidophilus } \\
\text { Staphylococcus aureus } \\
\text { Salmonella typhimurium }\end{array}$ & $\begin{array}{l}\uparrow \\
\uparrow \\
\uparrow \\
\uparrow \\
\downarrow \\
\downarrow\end{array}$ & [63] \\
\hline Bac & $\begin{array}{l}\text { Mv deriv } \\
\text { (red grape) }\end{array}$ & in vitro & & E. coli & $\downarrow$ & [64] \\
\hline Human & $\begin{array}{l}\text { Cy and Pn deriv } \\
\text { (purple sweet } \\
\text { potato) }\end{array}$ & $\begin{array}{l}\text { anaerobic } \\
\text { culture }\end{array}$ & $\begin{array}{l}\text { protocatechuic, phloroglucinol } \\
\text { aldehyde, syringic acid, } \\
\text { phloroglucinol aldehyde }\end{array}$ & $\begin{array}{l}\text { Bifidobacterium and } \\
\text { Lactobacillus/Enterococcus } \\
\text { Bacteroides-Prevotella Clostridium } \\
\text { histolyticum }\end{array}$ & $\begin{array}{l}\uparrow \\
\downarrow\end{array}$ & [65] \\
\hline Human & $\begin{array}{c}\text { P3G } \\
\text { (Strawberry) } \\
\text { M3G (red grape) }\end{array}$ & $\begin{array}{l}\text { anaerobic } \\
\text { culture }\end{array}$ & $\begin{array}{l}p \text {-hydroxybenzoic acid tyrosol, } \\
\text { Hydroxyphenylacetic. } \\
\text { Syringic, vanillic, } \\
\text { Hydroxyphenylpropionic acid }\end{array}$ & & & [66] \\
\hline Human & M3G (Red wine) & $\begin{array}{l}\text { anaerobic } \\
\text { culture }\end{array}$ & syringic acid & $\begin{array}{l}\text { Bifidobacterium spp., } \\
\text { Lactobacillus spp. } \\
\text { total number }\end{array}$ & $\uparrow$ & [67] \\
\hline Human & C3G, D3R, M3G & $\begin{array}{l}\text { anaerobic } \\
\text { culture }\end{array}$ & $\begin{array}{l}\text { ferulic, gallic, syringic } \\
\text { gallic acid }\end{array}$ & $\begin{array}{l}\text { C. histolyticum } \\
\text { total number }\end{array}$ & $\begin{array}{l}\downarrow \\
\uparrow\end{array}$ & [68] \\
\hline Human & C3G, C3R & $\begin{array}{l}\text { anaerobic } \\
\text { culture }\end{array}$ & $\begin{array}{l}\text { Protocatechuic acid } \\
\text { (3,4-dihydroxybenzoic acid), } \\
\text { cyanidin }\end{array}$ & & & [69] \\
\hline Human & $\begin{array}{l}\text { C3R, C3G, M3G, } \\
\text { P3R, P3G (jucara } \\
\text { pulp) }\end{array}$ & $\begin{array}{l}\text { anaerobic } \\
\text { culture }\end{array}$ & $\begin{array}{l}\text { gallic acid, syringic acid, benzoic } \\
\text { acid }\end{array}$ & $\begin{array}{l}\text { Bifidobacterium, Eubacterium } \\
\text { rectale/ Clostridium coccoides, } \\
\text { Bacteroides/Prevotella group }\end{array}$ & $\uparrow$ & [70] \\
\hline Human & $\begin{array}{l}\text { C3G, C3GR } \\
\text { (raspberry) }\end{array}$ & $\begin{array}{l}\text { anaerobic } \\
\text { culture }\end{array}$ & $\begin{array}{l}\text { 3,4-Dihydroxybenzoic acid, tyrosol, } \\
\text { catechol, resorcinol, pyrogallol }\end{array}$ & & & [71] \\
\hline Human & $\begin{array}{c}\text { M3G, Pn3G, } \\
\text { Pt3G (red wine) }\end{array}$ & $\begin{array}{l}\text { anaerobic } \\
\text { culture }\end{array}$ & $\begin{array}{l}\text { dihydroxylated benzene, } \\
\text { catechol/pyrocatechol, syringic } \\
\text { acid }\end{array}$ & $\begin{array}{l}\text { Bifidobacterium spp. } \\
\text { Lactobacillus/Enterococcus } \\
\text { Bacteroides }\end{array}$ & $\begin{array}{l}\mathrm{NC} \\
\mathrm{NC}\end{array}$ & [56] \\
\hline Human & $\begin{array}{c}\text { C3Ga, C3A } \\
\text { (Arbutus unedo) }\end{array}$ & $\begin{array}{l}\text { anaerobic } \\
\text { culture }\end{array}$ & 3,4-(Dihydroxyphenyl)-acetic acid & & & [72] \\
\hline Human & $\begin{array}{l}\text { Pn3G, MGa } \\
\text { (blueberry) }\end{array}$ & In vivo & & $\begin{array}{l}\text { Bifidobacterium } \\
\text { Lactobacillus acidophilus }\end{array}$ & $\uparrow$ & [73] \\
\hline Human & M3G (red wine) & In vivo & $\begin{array}{l}\text { syringic acid, p-coumaric acid, } \\
\text { 4-hydroxybenzoic, homovanillic } \\
\text { acid }\end{array}$ & Bifidobacterium & $\uparrow$ & [74] \\
\hline
\end{tabular}

C3G: cyanidin-3-glucoside; C3R: cyanidin-3-rutinoside; C3GR: cyanidin-3-glucosyl-rutinoside; Pn: Peonidin; Mv: malvidin; D3R: delphinidin-3-rutinoside; M3G: malvidin-3-glucoside; P3G: pelargodin-3-glucoside; P3R; pelargonidin-3-rutinoside; Cy: cyanidin; Pt3G: petunidin-3-glucoside; C3Ga: cyanidin-3-galactoside; C3A: cyandin-3-arabinoside; Pn3G; peonidin-3-glucoside; MGa: malvidin galactoside; Bac: bacteria; deriv: derivatives; Ef: sense of the regulation, effect; $\uparrow:$ increase in bacterial growth; $\downarrow$ : decrease in bacterial groth; NC: no change.

Early in vitro studies revealed that bacterial metabolism of anthocyanins leads to the cleavage of glycosidic linkages and breakdown of the anthocyanidin heterocycle. As a result of this breakdown, anthocyanins generate new metabolites via gut microbiota. The type and amount of these metabolites hinge on the structure of food matrix, anthocyanin source, gut composition, and bacterial interaction with anthocyanins [68,69]. After colonic fermentation, different gut metabolites are formed from different anthocyanins. For example, after the gut metabolism of cyanidin derivatives, the metabolites generally formed are protocatechuic acid, vanillic acid and p-coumaric acid, 2,4,6-trihydroxybenzaldehyde, gallic acid, syringic acid and 2,4,6-trihydroxybenzaldehyde, 2,3-dihydroxybenzoic acid, 3-hydroxycinnamic acid, and 3-hydroxyphenylpropionic acid [41,60,75,76]. On the other hand, malvidin derivatives bring in syringic acid, p-coumaric acid, 4-hydroxybenzoic, and 
homovanillic acid [67,74], and pelargonidin-3-glucoside produces tyrosol, hydroxyphenylpropionic acid, hydroxyphenylacetic acid, and p-hydroxybenzoic acid [66].

Table 4. Microbial metabolites of anthocyanins.

\begin{tabular}{|c|c|c|c|c|}
\hline Species & Anthocyanins & Model & Metabolites Found & Reference \\
\hline Pig & $\begin{array}{l}\text { D3G, PT3G, P3G, } \\
\text { M3G (red grape) }\end{array}$ & anaerobic culture & $\begin{array}{l}\text { 3-O-methylgallic acid, syringic acid, } \\
\text { 2,4,6-trihydroxybenzaldehyde }\end{array}$ & [77] \\
\hline Rat & $\begin{array}{l}\text { C3G, C3R, D3R } \\
\text { (mulberry) }\end{array}$ & anaerobic culture & $\begin{array}{l}\text { protocatechuic, vanillic, } p \text {-coumaric acid, } \\
\text { 2,4,6-trihydroxybenzaldehyde, gallic acid, } \\
\text { syringic acid, 2,4,6-triOHbenzaldehyde }\end{array}$ & [76] \\
\hline Rat & $\begin{array}{l}\text { Cy deriv (Black } \\
\text { raspberry) }\end{array}$ & In vivo & $\begin{array}{l}\text { 3-OHphenylpropionic, 3-hydroxybenzoic, } \\
\text { 3-OHcinnamic acids }\end{array}$ & [75] \\
\hline Rat & C $3 G$ & In vivo & protocatechuic acid & [41] \\
\hline
\end{tabular}

C3G: cyanidin-3-glucoside; D3R: delphinidin-3-rutinoside; M3G: malvidin-3-glucoside; C3R: cyanidin-3-rutinoside Pn: P3G: peonidin-3-glucoside; Cy deriv: cyanidin derivatives.

Other recent studies have shown that red wine and red wine products, which are rich sources of anthocyanin, produce syringic acid, dihydroxylated benzene, catechol/pyrocatechol, vanillic acid, protocatechuic acid, 3-O-methylgallic acid, and 2,4,6-trihydroxybenzaldehyde after colonic fermentation $[67,69,77]$. However, Sánchez-Patán et al. [56] did not observe a significant increase in protocatechuic, gallic and vanillic acid levels during fecal fermentation of a similar polyphenol source.

Berries are one of the most studied fruits regarding anthocyanin metabolism. Several studies with human feces and rat feces have shown that protocatechuic, 3-hydroxyphenylpropionic, pyrogallol, 3,4-dihydroxybenzoic acid, and tyrosol are the main metabolites formed after colonic fermentation of berries. These studies prove that mono and di-glycosidic anthocyanins are rapidly catabolized by colonic microbiota [71,76]. In some cases, the production of specific metabolites, that is, O-methylated metabolites from malvidin and petunidin increase their bioactivity [78] (Table 5). On the other hand, glycosylation and acetylation of anthocyanins, while conferring increased stability in the gastrointestinal tract, showed a decreased bioactivity. Some authors have reported hippuric acid as the main anthocyanin metabolite derived from microbial metabolism, however, it is well known that hippuric acid is a rather unspecific metabolite that can be formed after ingestion of other families of polyphenols (i.e., proanthocyanins) [75].

Besides, Cheng et al. [61] studied five intestinal bacteria after incubation with mulberry anthocyanins under anaerobic conditions and identified chlorogenic acid, cryptochlorogenic acid, caffeic acid, and ferulic acid. They concluded that protocatechuic acid, chlorogenic acid, and ferulic acid are microbial metabolites formed by bacterial $\beta$-glucosidase action. However, they proposed that the production of chlorogenic acid and cryptochlorogenic acid were derived from chemical degradation of anthocyanins and not from bacterial action. However, it should be noted that chlorogenic and cryptochlorogenic acids might well derive from other compounds present in the extract and not only from anthocyanins. 
Table 5. Gut bacteria regulated by anthocyanins.

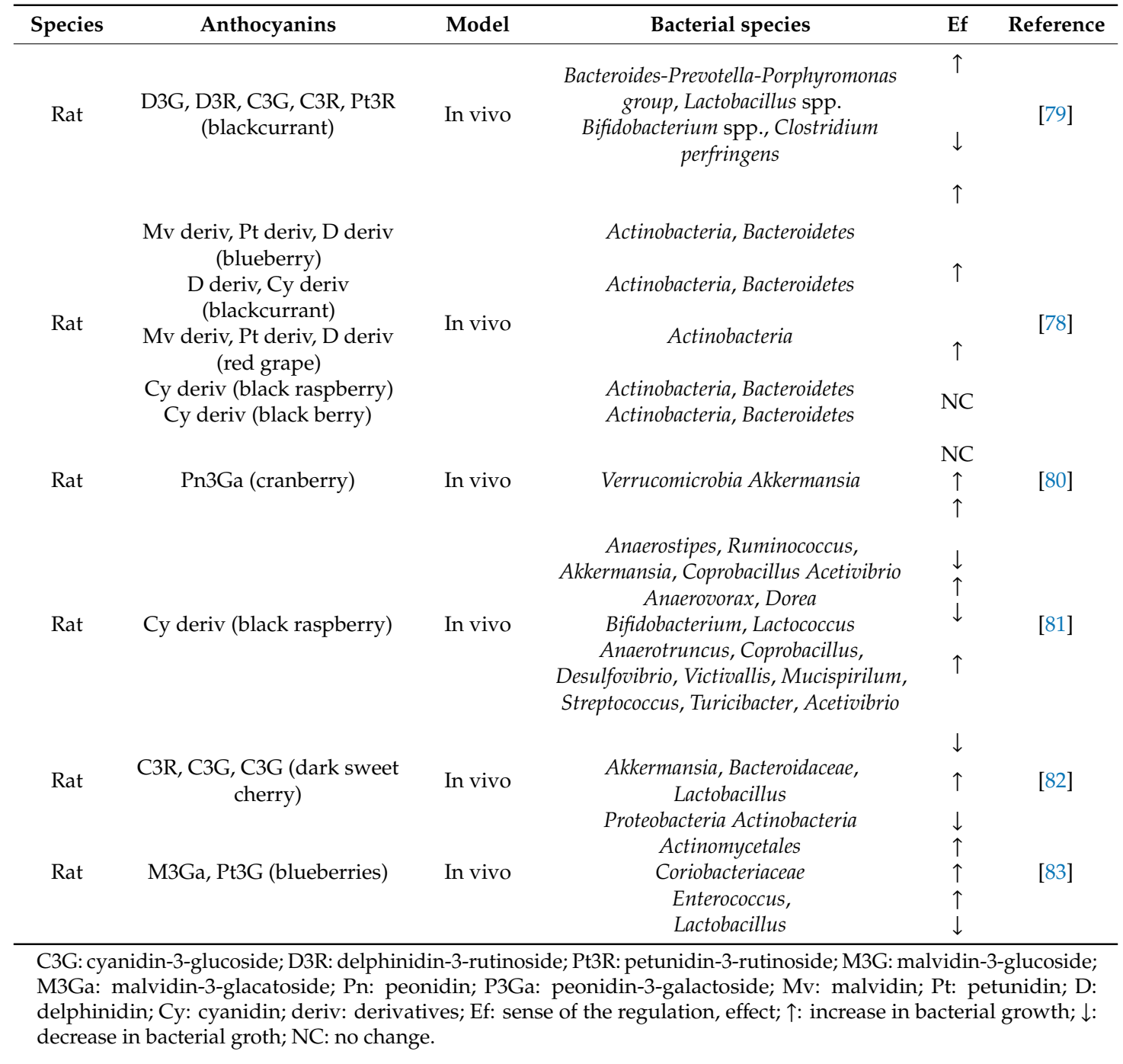

In general, most authors analyze anthocyanin metabolites in in vitro fermentation or in vivo ingestion assays after $8 \mathrm{~h}$ or longer. Faria et al. [84] showed that the highest recovery of anthocyanin metabolites in feces was seen after $24 \mathrm{~h}$ of consumption. Czank et al. [43] reported that a remarkable part of cyanidin-3-glucoside metabolites did not reach maximal concentrations in fecal samples until $48 \mathrm{~h}$ of interaction. They proposed, in this sense, that a longer fecal sampling period (perhaps $\geq 72 \mathrm{~h}$ ) might show better recoveries. However, some of the fermentation studies showing the presence of the aglycon cyanidin or the formation of the glucoside of cyanidin after fermentation of the rutinoside used shorter times (e.g., $2 \mathrm{~h}$ in Aura et al. [69]).

Several authors have shown that bacterial enzymatic activity affects the catabolism of anthocyanins. Generally, intestinal microbiota has $\beta$ - $D$-glucosidase, $\beta$ - $D$-glucuronidase, $\alpha$-galactosidase, and $\alpha$-rhamnosidase activity. Gut microbiota breaking of glycosidic linkages and breakdown of anthocyanidin heterocycle are both meditated via bacterial enzymatic activity. This way, anthocyanins are transformed into their more bioavailable forms that, in turn, may regulate the colonic microbiota composition (Figure 2) $[61,76,81,84]$.

Many studies reveal that after the consumption of anthocyanins, beneficial bacteria such as Bifidobacterium spp., Lactobacillus spp., or Actinobacteria populations are increased in the gut microbiota $[61-63,73,79,82]$. These bacteria contribute in different ways to human health as they participate in the metabolism of phenolic compounds, enhance gut barrier function, increase mucus secretion, produce short-chain fatty acids, or regulate lipid metabolism (see Figure 2) [82,84]. 
A recent in vitro work with bacterial strains demonstrated that after the incubation of black rice anthocyanins, Bifidobacteria and Lactobacillus increased and pH values decreased [62]. Similarly, Sun et al. [63] reported that after the incubation of peonidin derivatives with different bacterial strains, the $\mathrm{pH}$ values decreased and the bacterial growing rate of Bifidobacterium bifidum, Bifidobacterium adolescentis, Bifidobacterium infantis, and Lactobacillus acidophilus increased. They concluded that the metabolism of anthocyanins by microbiota bacteria produces the breakdown of $\beta$-glucoside bonds and the production of short-chain fatty acids (SCFA) alongside phenolic acids, which triggers the decrease of $\mathrm{pH}$ and ensures a suitable media for proliferation of probiotic bacteria.

In another study, after the colonic metabolism of jucara pulp, Guergoletto et al. [70] observed that although Lactobacillus/Enterococcus spp. did not modify their growing rate, Bifidobacterium spp., Eubacterium rectale-Clostridium coccoides group, and Bacteroides spp.-Prevotella group did. In parallel, there was an increase in SCFA levels. In a similar way, dietary cherry supplementation promotes SCFA production in gut microbiota and provides an increase in beneficial bacteria (i.e., Bacteroidaceae, Akkermansia), in this case showing that the increase in SCFA is associated with Akkermansia [82]. Similarly, Anhê et al. [80] showed that after consumption of a cranberry extract, there was an increase in Akkermansia that was associated with an enhancement of the gut barrier function via mucus secretion stimulation. In the light of all the above, we can conclude that anthocyanins are metabolized by specific bacteria in the gut microbiota and that, in turn, they are able to modify selectively the growing rate of specific bacterial groups $[63,65,85]$. Moreover, gut microbiota is extremely complex and shows large variability, both intra-individually and inter-individually, depending on the age, body weight, genetics, disease state, and dietary habits. Therefore, we could assume that much of the variability on anthocyanins ADME could be due to changes in microbiota composition [82,85].

Although many studies reported that after anthocyanin colonic fermentation many beneficial bacteria like Bifidobacterium spp., Actinobacteria, Bacteroidetes, Lactobacillus/Enterococcus spp., Akkermansia [62,67,74,80,82,83] increase, Sánchez-Patán et al. [56] failed to show any change for Bifidobacterium spp., Lactobacillus/Enterococcus spp., Bacteroides. On the other hand, Overall et al. [78] showed that different profiles of anthocyanins from different sources can have a different impact on the gut microbiota. After colonic fermentation of black berry and black raspberry, Actinobacteria levels remained unchanged, while they proliferated with concord grape, blackcurrant, or blueberry [78]. Besides, they showed that after the consumption of the berries there was a reduction in oxygen tension in the gut lumen that lead to the growth of oxygen-sensitive bacteria.

Anthocyanins can not only enhance beneficial bacteria in gut microbiota, but also reduce some harmful bacteria. Guergoletto et al. [70] and Flores et al. [68] showed that C. histolyticum is significantly decreased after colonic fermentation of certain anthocyanins (cyanidin and delphinidin derivatives mainly). However, this effect did not show up when the source of anthocyanin was malvidin-3-glucoside [68]. In addition, Hidalgo et al. [67] indicated that after the colonic fermentation of malvidin-3-glucoside, C. histolyticum decreased, although not significantly. Similarly, Sánchez-Patán et al. [56] observed a slight but not significant inhibition of $C$. histolyticum, but did not detect any changes in beneficial bacteria. Trikas et al. [64] reported that anthocyanins of wine and wine by-product extracts inhibited E. coli and S. aureus. Similarly, Lacombe et al. [83] showed that Enterococcus is decreased in feces of rat that were feed with low-bush berry for 6 weeks. These recent studies proved that anthocyanins have the capacity to modulate gut microbiota, bringing out beneficial changes (see Figure 2). 


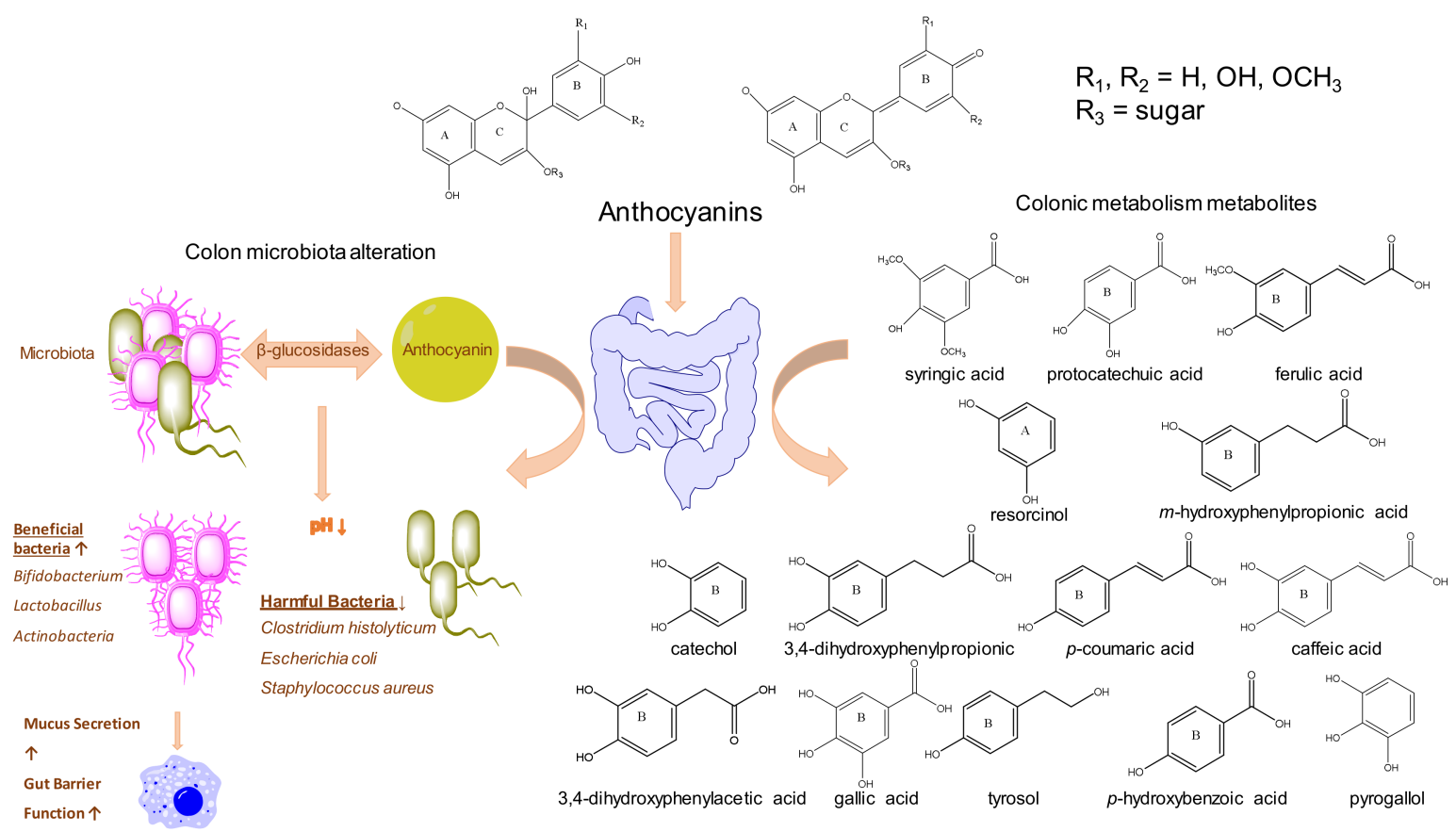

Figure 2. Scheme of Anthocyanins ADME (absorption, metabolism, distribution, and excretion) and structure of the main metabolites.

It is difficult to concretely conclude on anthocyanin metabolism and biotransformation by the gut microbiota. Although the scientific literature differs in many ways, such as the source of anthocyanins, food matrix, or in vivo or in vitro model, it can be concluded that anthocyanins and their metabolites generally have a positive impact on microbiota. However, this effect may show variability depending on genetic, physiological, and pathological state. Therefore, the metabolism of anthocyanins by gut microflora and the associated inter-individual variability is an aspect that needs to be better studied in the future.

\section{Conclusions}

There is an evident inter- and intra-individual variability in anthocyanins ADME that will undoubtedly have an effect on anthocyanins efficacy. There are, however, only few studies published so far that describe this variability and even less that aimed to study the role of different of different factors on this inter or intra-individual variability. Nonetheless, looking at the existing bibliography we could assume that there are three main factors that will likely affect anthocyanins ADME, which are food matrix and food processing, enzymatic levels that, in turn, are affected by genetic factors, but also by the diet, age, sex, and so forth, and the microbiota functionality, which again can be modified depending on age, diet, physiological, genetic, and pathological factors.

It is clear from the literature currently available that, even if some of the described metabolites generated through gut bacteria metabolism are quite robust and can probably be used as biomarkers of anthocyanin consumption, more studies are needed in order to establish which species are involved in anthocyanin metabolism in order to clarify the effect of microbiota variability on the inter-individual variation encountered in humans in terms of anthocyanin bioavailability. One can assume that the breakdown products generated from anthocyanins are due either to nonenzymatic degradation or to microbiota activity, but at the moment there are not enough studies in which we can base solid conclusions.

Author Contributions: All authors contributed to literature search and original draft preparation; Writing-review and editing of final version was done by M.E.E., K.A., W.W., C.M. and S.d.P.-T. All authors have read and agreed to the published version of the manuscript. 
Funding: The authors thank the financial support of the COST Action FA1403-POSITIVe "Interindividual variation in response to consumption of plant food bioactives and determinants involved" supported by COST (European Cooperation in Science and Technology, http://www.cost.eu/) to conduct a short-term scientific mission (STSM) to M.E.E. at ICTAN-CSIC (S.d.P.-T.) during which most of the data collection was performed.

Conflicts of Interest: The authors declare no conflict of interest.

\section{References}

1. De Pascual-Teresa, S.; Moreno, D.A.; García-Viguera, C. Flavanols and anthocyanins in cardiovascular health: A review of current evidence. Int. J. Mol. Sci. 2010, 11, 1679-1703. [CrossRef] [PubMed]

2. He, J.; Giusti, M.M. Anthocyanins: Natural colorants with health-promoting properties. Annu. Rev. Food Sci. Technol. 2010, 1, 163-187. [CrossRef] [PubMed]

3. Pojer, E.; Mattivi, F.; Johnson, D.; Stockley, C.S. The case for anthocyanin consumption to promote human health: A review. Compr. Rev. Food Sci. Food Saf. 2013, 12, 483-508. [CrossRef]

4. Kent, K.; Charlton, K.E.; Netzel, M.; Fanning, K. Food-based anthocyanin intake and cognitive outcomes in human intervention trials: A systematic review. J. Hum. Nutr. Diet. 2017, 30, 260-274. [CrossRef]

5. Fairlie-Jones, L.; Davison, K.; Fromentin, E.; Hill, A.M. The effect of anthocyanin-rich foods or extracts on vascular function in adults: A systematic review and meta-analysis of randomised controlled trials. Nutrients 2017, 9, 908. [CrossRef]

6. García-Conesa, M.T.; Chambers, K.; Combet, E.; Pinto, P.; Garcia-Aloy, M.; Andrés-Lacueva, C.; de Pascual-Teresa, S.; Mena, P.; Ristic, A.K.; Hollands, W.J.; et al. Meta-analysis of the effects of foods and derived products containing ellagitannins and anthocyanins on cardiometabolic biomarkers: Analysis of factors influencing variability of the individual responses. Int. J. Mol. Sci. 2018, 19, 694. [CrossRef]

7. Clifford, M.N. Anthocyanins-Nature, occurrence and dietary sources. J. Sci. Food Agric. 2000, 80, 1063-1072. [CrossRef]

8. Mazza, G.; Miniati, E. Anthocyanins in Fruits, Vegetables, and Grains; CRC Press: Boca Raton, FL, USA, 1993; ISBN 9781315890609.

9. Andersen, Ø.M.; Jordheim, M. The Anthocyanins. Chemistry, Biochemistry and Applications; Andersen, Ø.M., Markham, K.R., Eds.; CRC Press: Boca Raton, FL, USA, 2006; pp. 471-553. ISBN 9780849320217.

10. Wu, X.; Beecher, G.R.; Holden, J.M.; Haytowitz, D.B.; Gebhardt, S.E.; Prior, R.L. Concentrations of anthocyanins in common foods in the United States and estimation of normal consumption. J. Agric. Food Chem. 2006, 54, 4069-4075. [CrossRef]

11. Koponen, J.M.; Happonen, A.M.; Mattila, P.H.; Törrönen, A.R. Contents of anthocyanins and ellagitannins in selected foods consumed in Finland. J. Agric. Food Chem. 2007, 55, 1612-1619. [CrossRef]

12. Olivas-Aguirre, F.J.; Rodrigo-García, J.; Martínez-Ruiz, N.D.R.; Cárdenas-Robles, A.I.; Mendoza-Díaz, S.O.; Álvarez-Parrilla, E.; González-Aguilar, G.A.; De La Rosa, L.A.; Ramos-Jiménez, A.; Wall-Medrano, A. Cyanidin-3-O-glucoside: Physical-chemistry, foodomics and health effects. Molecules 2016, 21, 1264. [CrossRef]

13. Jennings, A.; Welch, A.A.; Fairweather-Tait, S.J.; Kay, C.; Minihane, A.M.; Chowienczyk, P.; Jiang, B.; Cecelja, M.; Spector, T.; Macgregor, A.; et al. Higher anthocyanin intake is associated with lower arterial stiffness and central blood pressure in women. Am. J. Clin. Nutr. 2012, 96, 781-788. [CrossRef] [PubMed]

14. Cavalcanti, R.N.; Santos, D.T.; Meireles, M.A.A. Non-thermal stabilization mechanisms of anthocyanins in model and food systems-An overview. Food Res. Int. 2011, 44, 499-509. [CrossRef]

15. Charron, C.S.; Kurilich, A.C.; Clevidence, B.A.; Simon, P.W.; Harrison, D.J.; Britz, S.J.; Baer, D.J.; Novotny, J.A. Bioavailability of anthocyanins from purple carrot juice: Effects of acylation and plant matrix. J. Agric. Food Chem. 2009, 57, 1226-1230. [CrossRef] [PubMed]

16. Novotny, J.A.; Clevidence, B.A.; Kurilich, A.C. Anthocyanin kinetics are dependent on anthocyanin structure. Br. J. Nutr. 2012, 107, 504-509. [CrossRef]

17. Felgines, C.; Texier, O.; Besson, C.; Lyan, B.; Lamaison, J.L.; Scalbert, A. Strawberry pelargonidin glycosides are excreted in urine as intact glycosides and glucuronidated pelargonidin derivatives in rats. Br. J. Nutr. 2007, 98, 1126-1131. [CrossRef]

18. Barba, F.J.; Nikmaram, N.; Roohinejad, S.; Khelfa, A.; Zhu, Z.; Koubaa, M. Bioavailability of glucosinolates and their breakdown products: Impact of processing. Front. Nutr. 2016, 3, 1-12. [CrossRef] 
19. Celli, G.B.; Brooks, M.S.L. Impact of extraction and processing conditions on betalains and comparison of properties with anthocyanins-A current review. Food Res. Int. 2017, 100, 501-509. [CrossRef]

20. Kurilich, A.C.; Clevidence, B.A.; Britz, S.J.; Simon, P.W.; Novotny, J.A. Plasma and urine responses are lower for acylated vs nonacylated anthocyanins from raw and cooked purple carrots. J. Agric. Food Chem. 2005, 53, 6537-6542. [CrossRef]

21. Hollands, W.; Brett, G.M.; Radreau, P.; Saha, S.; Teucher, B.; Bennett, R.N.; Kroon, P.A. Processing blackcurrants dramatically reduces the content and does not enhance the urinary yield of anthocyanins in human subjects. Food Chem. 2008, 108, 869-878. [CrossRef]

22. Del Bo', C.; Riso, P.; Brambilla, A.; Gardana, C.; Rizzolo, A.; Simonetti, P.; Bertolo, G.; Klimis-Zacas, D.; Porrini, M. Blanching improves anthocyanin absorption from highbush blueberry (Vaccinium corymbosum L.) purée in healthy human volunteers: A pilot study. J. Agric. Food Chem. 2012, 60, 9298-9304. [CrossRef]

23. Tomas, M.; Toydemir, G.; Boyacioglu, D.; Hall, R.; Beekwilder, J.; Capanoglu, E. The effects of juice processing on black mulberry antioxidants. Food Chem. 2015, 186, 277-284. [CrossRef] [PubMed]

24. Kuntz, S.; Rudloff, S.; Asseburg, H.; Borsch, C.; Fröhling, B.; Unger, F.; Dold, S.; Spengler, B.; Römpp, A.; Kunz, C. Uptake and bioavailability of anthocyanins and phenolic acids from grape/blueberry juice and smoothie in vitro and in vivo. Br. J. Nutr. 2015, 113, 1044-1055. [CrossRef] [PubMed]

25. Wiczkowski, W.; Szawara-Nowak, D.; Romaszko, J. The impact of red cabbage fermentation on bioavailability of anthocyanins and antioxidant capacity of human plasma. Food Chem. 2016, 190, 730-740. [CrossRef] [PubMed]

26. Pineda-Vadillo, C.; Nau, F.; Guerin-Dubiard, C.; Jardin, J.; Lechevalier, V.; Sanz-Buenhombre, M.; Guadarrama, A.; Tóth, T.; Csavajda, É.; Hingyi, H.; et al. The food matrix affects the anthocyanin profile of fortified egg and dairy matrices during processing and in vitro digestion. Food Chem. 2017, 214, 486-496. [CrossRef] [PubMed]

27. Yang, M.; Koo, S.I.; Song, W.O.; Chun, O.K. Food matrix affecting anthocyanin bioavailability: Review. Curr. Med. Chem. 2011, 18, 291-300. [CrossRef]

28. Nielsen, I.L.F.; Dragsted, L.O.; Ravn-haren, G.; Freese, R.; Rasmussen, S.E. Absorption and excretion of black currant anthocyanins in humans and watanabe heritable hyperlipidemic rabbits. J. Agric. Food Chem. 2003, 51, 2813-2820. [CrossRef]

29. Mullen, W.; Edwards, C.A.; Serafini, M.; Crozier, A. Bioavailability of pelargonidin-3-O-glucoside and its metabolites in humans following the ingestion of strawberries with and without cream. J. Agric. Food Chem. 2008, 56, 713-719. [CrossRef]

30. Serafini, M.; Bugianesi, R.; Maiani, G.; Valtuena, S.; De Santis, S.; Crozier, A. Plasma antioxidants from chocolate. Nature 2003, 424, 1013. [CrossRef]

31. Bub, A.; Watzl, B.; Heeb, D.; Rechkemmer, G.; Briviba, K. Malvidin-3-glucoside bioavailability in humans after ingestion of red wine, dealcoholized red wine and red grape juice. Eur. J. Nutr. 2001, 40, 113-120. [CrossRef]

32. Mülleder, U.; Murkovic, M.; Pfannhauser, W. Urinary excretion of cyanidin glycosides. J. Biochem. Biophys. Methods 2002, 53, 61-66. [CrossRef]

33. Walton, M.C.; Lentle, R.G.; Reynolds, G.W.; Kruger, M.C.; McGhie, T.K. Anthocyanin absorption and antioxidant status in pigs. J. Agric. Food Chem. 2006, 54, 7940-7946. [CrossRef] [PubMed]

34. Frank, T.; Netzel, M.; Strass, G.; Bitsch, R.; Bitsch, I. Bioavailability of anthocyanidin-3-glucosides following consumption of red wine and red grape juice. Can. J. Physiol. Pharmacol. 2003, 81, 423-435. [CrossRef] [PubMed]

35. McDougall, G.J.; Dobson, P.; Smith, P.; Blake, A.; Stewart, D. Assessing potential bioavailability of raspberry anthocyanins using an in vitro digestion system. J. Agric. Food Chem. 2005, 53, 5896-5904. [CrossRef] [PubMed]

36. Sengul, H.; Surek, E.; Nilufer-Erdil, D. Investigating the effects of food matrix and food components on bioaccessibility of pomegranate (Punica granatum) phenolics and anthocyanins using an in-vitro gastrointestinal digestion model. Food Res. Int. 2014, 62, 1069-1079. [CrossRef]

37. Ribnicky, D.M.; Roopchand, D.E.; Oren, A.; Grace, M.; Poulev, A.; Lila, M.A.; Havenaar, R.; Raskin, I. Effects of a high fat meal matrix and protein complexation on the bioaccessibility of blueberry anthocyanins using the TNO gastrointestinal model (TIM-1). Food Chem. 2014, 142, 349-357. [CrossRef] [PubMed] 
38. Karakaya, S.; Simsek, S.; Eker, A.T.; Pineda-Vadillo, C.; Dupont, D.; Perez, B.; Viadel, B.; Sanz-Buenhombre, M.; Rodriguez, A.G.; Kertész, Z.; et al. Stability and bioaccessibility of anthocyanins in bakery products enriched with anthocyanins. Food Funct. 2016, 7, 3488-3496. [CrossRef] [PubMed]

39. Manach, C.; Williamson, G.; Morand, C.; Scalbert, A.; Rémésy, C. Bioavailability and bioefficacy of polyphenols in humans. I. Review of 97 bioavailability studies. Am. J. Clin. Nutr. 2005, 81, 230-242. [CrossRef]

40. Rodriguez-Mateos, A.; Vauzour, D.; Krueger, C.G.; Shanmuganayagam, D.; Reed, J.; Calani, L.; Mena, P.; Del Rio, D.; Crozier, A. Bioavailability, bioactivity and impact on health of dietary flavonoids and related compounds: An update. Arch. Toxicol. 2014, 88, 1803-1853. [CrossRef]

41. Wang, D.; Xia, M.; Yan, X.; Li, D.; Wang, L.; Xu, Y.; Jin, T.; Ling, W. Gut microbiota metabolism of anthocyanin promotes reverse cholesterol transport in mice via repressing miRNA-10b. Circ. Res. 2012, 111, 967-981. [CrossRef]

42. Pimpão, R.C.; Ventura, M.R.; Ferreira, R.B.; Williamson, G.; Santos, C.N. Phenolic sulfates as new and highly abundant metabolites in human plasma after ingestion of a mixed berry fruit purée. Br. J. Nutr. 2015, 113, 454-463. [CrossRef]

43. Czank, C.; Cassidy, A.; Zhang, Q.; Morrison, D.J.; Preston, T.; Kroon, P.A.; Botting, N.P.; Kay, C.D. Human metabolism and elimination of the anthocyanin, cyanidin-3-glucoside: A 13C-tracer study. Am. J. Clin. Nutr. 2013, 97, 995-1003. [CrossRef] [PubMed]

44. Wu, B.; Kulkarni, K.; Basu, S.; Zhang, S.; Hu, M. First-pass metabolism via UDP-glucuronosyltransferase: A barrier to oral bioavailability of phenolics. J. Pharm. Sci. 2011, 100, 3655-3681. [CrossRef] [PubMed]

45. Fernandes, I.; Faria, A.; Calhau, C.; de Freitas, V.; Mateus, N. Bioavailability of anthocyanins and derivatives. J. Funct. Foods 2014, 7, 54-66. [CrossRef]

46. Court, M.H. Interindividual variability in hepatic drug glucuronidation: Studies into the role of age, sex, enzyme inducers, and genetic polymorphism using the human liver bank as a model system. Drug Metab. Rev. 2010, 42, 202-217. [CrossRef]

47. Strassburg, C.P.; Strassburg, A.; Kneip, S.; Barut, A.; Tukey, R.H.; Rodeck, B.; Manns, M.P. Developmental aspects of human hepatic drug glucuronidation in young children and adults. Gut 2002, 50, 259-265. [CrossRef]

48. Bolling, B.W.; Court, M.H.; Blumberg, J.B.; Chen, C.Y.O. The kinetic basis for age-associated changes in quercetin and genistein glucuronidation by rat liver microsomes. J. Nutr. Biochem. 2010, 21, 498-503. [CrossRef]

49. Buckley, D.B.; Klaassen, C.D. Tissue- and gender-specific mRNA expression of UDP-glucuronosyltransferases (UGTs) in mice. Drug Metab. Dispos. 2007, 35, 121-127. [CrossRef]

50. Navarro, S.L.; Peterson, S.; Chen, C.; Makar, K.W.; Schwarz, Y.; King, I.B.; Li, S.S.; Li, L.; Kestin, M.; Lampe, J.W. Cruciferous vegetable feeding alters UGT1A1 activity: Diet- and genotype-dependent changes in serum bilirubin in a controlled feeding trial. Cancer Prev. Res. 2009, 2, 345-352. [CrossRef]

51. Németh, K.; Plumb, G.W.; Berrin, J.G.; Juge, N.; Jacob, R.; Naim, H.Y.; Williamson, G.; Swallow, D.M.; Kroon, P.A. Deglycosylation by small intestinal epithelial cell $\beta$-glucosidases is a critical step in the absorption and metabolism of dietary flavonoid glycosides in humans. Eur. J. Nutr. 2003, 42, 29-42. [CrossRef]

52. Mallery, S.R.; Budendorf, D.E.; Larsen, M.P.; Pei, P.; Tong, M.; Holpuch, A.S.; Larsen, P.E.; Stoner, G.D.; Fields, H.W.; Chan, K.K.; et al. Effects of human oral mucosal tissue, saliva and oral microflora on intraoral metabolism and bioactivation of black raspberry anthocyanins. Cancer Prev. Res. 2011, 4, 1209-1221. [CrossRef]

53. Riches, Z.; Stanley, E.L.; Bloomer, J.C.; Coughtrie, M.W.H. Quantitative evaluation of the expression and activity of five major sulfotransferases (SULTs) in human tissues: The SULT pie. Drug Metab. Dispos. 2009, 37, 2255-2261. [CrossRef]

54. Bai, H.W.; Shim, J.Y.; Yu, J.; Bao, T.Z. Biochemical and molecular modeling studies of the O-methylation of various endogenous and exogenous catechol substrates catalyzed by recombinant human soluble and membrane-bound catechol-O-methyltransferases. Chem. Res. Toxicol. 2007, 20, 1409-1425. [CrossRef]

55. Miller, R.J.; Jackson, K.G.; Dadd, T.; Mayes, A.E.; Brown, A.L.; Lovegrove, J.A.; Minihane, A.M. The impact of the catechol-O-methyltransferase genotype on vascular function and blood pressure after acute green tea ingestion. Mol. Nutr. Food Res. 2012, 56, 966-975. [CrossRef] 
56. Sánchez-Patán, F.; Cueva, C.; Monagas, M.; Walton, G.E.; Gibson, G.R.; Quintanilla-López, J.E.; Lebrón-Aguilar, R.; Martín-Álvarez, P.J.; Moreno-Arribas, M.V.; Bartolomé, B. In vitro fermentation of a red wine extract by human gut microbiota: Changes in microbial groups and formation of phenolic metabolites. J. Agric. Food Chem. 2012, 60, 2136-2147. [CrossRef]

57. Stalmach, A.; Edwards, C.A.; Wightman, J.D.; Crozier, A. Colonic catabolism of dietary phenolic and polyphenolic compounds from Concord grape juice. Food Funct. 2013, 4, 52-62. [CrossRef]

58. Ludwig, I.A.; Mena, P.; Calani, L.; Borges, G.; Pereira-Caro, G.; Bresciani, L.; Del Rio, D.; Lean, M.E.J.; Crozier, A. New insights into the bioavailability of red raspberry anthocyanins and ellagitannins. Free Radic. Biol. Med. 2015, 89, 758-769. [CrossRef]

59. Burgos-Edwards, A.; Jiménez-Aspee, F.; Theoduloz, C.; Schmeda-Hirschmann, G. Colonic fermentation of polyphenols from Chilean currants (Ribes spp.) and its effect on antioxidant capacity and metabolic syndrome-associated enzymes. Food Chem. 2018, 258, 144-155. [CrossRef]

60. Hanske, L.; Engst, W.; Loh, G.; Sczesny, S.; Blaut, M.; Braune, A. Contribution of gut bacteria to the metabolism of cyanidin 3-glucoside in human microbiota-associated rats. Br. J. Nutr. 2013, 109, 1433-1441. [CrossRef]

61. Cheng, J.R.; Liu, X.M.; Chen, Z.Y.; Zhang, Y.S.; Zhang, Y.H. Mulberry anthocyanin biotransformation by intestinal probiotics. Food Chem. 2016, 213, 721-727. [CrossRef]

62. Zhu, Y.; Sun, H.; He, S.; Lou, Q.; Yu, M.; Tang, M.; Tu, L. Metabolism and prebiotics activity of anthocyanins from black rice (Oryza sativa L.) in vitro. PLoS ONE 2018, 13, e0195754. [CrossRef]

63. Sun, H.; Zhang, P.; Zhu, Y.; Lou, Q.; He, S. Antioxidant and prebiotic activity of five peonidin-based anthocyanins extracted from purple sweet potato (Ipomoea batatas (L.) Lam.). Sci. Rep. 2018, 8, 1-12. [CrossRef]

64. Trikas, E.D.; Melidou, M.; Papi, R.M.; Zachariadis, G.A.; Kyriakidis, D.A. Extraction, separation and identification of anthocyanins from red wine by-product and their biological activities. J. Funct. Foods 2016, 25, 548-558. [CrossRef]

65. Zhang, P.; Zhang, M.; He, S.; Cao, X.; Sun, H.; Chen, X.; Xie, Y.; Lou, Q.; Wang, X.; Ye, Y. Extraction and probiotic properties of New anthocyanins from purple sweet potato (Solanum tuberosum). Curr. Top. Nutraceuticals Res. 2016, 14, 153-160.

66. López De Las Hazas, M.C.; Mosele, J.I.; Macià, A.; Ludwig, I.A.; Motilva, M.J. Exploring the colonic metabolism of grape and strawberry anthocyanins and their in vitro apoptotic effects in HT-29 Colon Cancer Cells. J. Agric. Food Chem. 2017, 65, 6477-6487. [CrossRef]

67. Hidalgo, M.; Oruna-Concha, M.J.; Kolida, S.; Walton, G.E.; Kallithraka, S.; Spencer, J.P.E.; Gibson, G.R.; de Pascual-Teresa, S. Metabolism of anthocyanins by human gut microflora and their influence on gut bacterial growth. J. Agric. Food Chem. 2012, 60, 3882-3890. [CrossRef]

68. Flores, G.; Ruiz del Castillo, M.L.; Costabile, A.; Klee, A.; Bigetti Guergoletto, K.; Gibson, G.R. In vitro fermentation of anthocyanins encapsulated with cyclodextrins: Release, metabolism and influence on gut microbiota growth. J. Funct. Foods 2015, 16, 50-57. [CrossRef]

69. Aura, A.M.; Martin-Lopez, P.; O’Leary, K.A.; Williamson, G.; Oksman-Caldentey, K.M.; Poutanen, K.; Santos-Buelga, C. In vitro metabolism of anthocyanins by human gut microflora. Eur. J. Nutr. 2005, 44, 133-142. [CrossRef]

70. Guergoletto, K.B.; Costabile, A.; Flores, G.; Garcia, S.; Gibson, G.R. In vitro fermentation of juçara pulp (Euterpe edulis) by human colonic microbiota. Food Chem. 2016, 196, 251-258. [CrossRef]

71. González-Barrio, R.; Edwards, C.A.; Crozier, A. Colonic catabolism of ellagitannins, ellagic acid, and raspberry anthocyanins: In vivo and in vitro studies. Drug Metab. Dispos. 2011, 39, 1680-1688. [CrossRef]

72. Mosele, J.I.; Macià, A.; Romero, M.P.; Motilva, M.J. Stability and metabolism of Arbutus unedo bioactive compounds (phenolics and antioxidants) under in vitro digestion and colonic fermentation. Food Chem. 2016, 201, 120-130. [CrossRef]

73. Vendrame, S.; Guglielmetti, S.; Riso, P.; Arioli, S.; Klimis-Zacas, D.; Porrini, M. Six-week consumption of a wild blueberry powder drink increases Bifidobacteria in the human gut. J. Agric. Food Chem. 2011, 59, 12815-12820. [CrossRef]

74. Boto-Ordóñez, M.; Urpi-Sarda, M.; Queipo-Ortuño, M.I.; Tulipani, S.; Tinahones, F.J.; Andres-Lacueva, C. High levels of Bifidobacteria are associated with increased levels of anthocyanin microbial metabolites: A randomized clinical trial. Food Funct. 2014, 5, 1932-1938. [CrossRef] 
75. Khanal, R.; Howard, L.R.; Prior, R.L. Urinary excretion of phenolic acids in rats fed cranberry, blueberry, or black raspberry powder. J. Agric. Food Chem. 2014, 62, 3987-3996. [CrossRef]

76. Chen, Y.; Li, Q.; Zhao, T.; Zhang, Z.; Mao, G.; Feng, W.; Wu, X.; Yang, L. Biotransformation and metabolism of three mulberry anthocyanin monomers by rat gut microflora. Food Chem. 2017, 237, 887-894. [CrossRef]

77. Forester, S.C.; Waterhouse, A.L. Identification of cabernet sauvignon anthocyanin gut microflora metabolites. J. Agric. Food Chem. 2008, 56, 9299-9304. [CrossRef]

78. Overall, J.; Bonney, S.A.; Wilson, M.; Beermann, A.; Grace, M.H.; Esposito, D.; Lila, M.A.; Komarnytsky, S. Metabolic effects of berries with structurally diverse anthocyanins. Int. J. Mol. Sci. 2017, 18, 422. [CrossRef]

79. Paturi, G.; Butts, C.A.; Monro, J.A.; Hedderley, D. Effects of blackcurrant and dietary fibers on large intestinal health biomarkers in rats. Plant Foods Hum. Nutr. 2018, 73, 54-60. [CrossRef]

80. Anhê, F.F.; Roy, D.; Pilon, G.; Dudonné, S.; Matamoros, S.; Varin, T.V.; Garofalo, C.; Moine, Q.; Desjardins, Y.; Levy, E.; et al. A polyphenol-rich cranberry extract protects from diet-induced obesity, insulin resistance and intestinal inflammation in association with increased Akkermansia spp. population in the gut microbiota of mice. Gut 2015, 64, 872-883. [CrossRef]

81. Pan, P.; Lam, V.; Salzman, N.; Huang, Y.W.; Yu, J.; Zhang, J.; Wang, L.S. Black raspberries and their anthocyanin and fiber fractions alter the composition and diversity of gut microbiota in F-344 rats. Nutr. Cancer 2017, 69, 943-951. [CrossRef]

82. Garcia-Mazcorro, J.F.; Lage, N.N.; Mertens-Talcott, S.; Talcott, S.; Chew, B.; Dowd, S.E.; Kawas, J.R.; Noratto, G.D. Effect of dark sweet cherry powder consumption on the gut microbiota, short-chain fatty acids, and biomarkers of gut health in obese $\mathrm{db} / \mathrm{db}$ mice. Peer J. 2018, 2018, 1-31. [CrossRef]

83. Lacombe, A.; Li, R.W.; Klimis-Zacas, D.; Kristo, A.S.; Tadepalli, S.; Krauss, E.; Young, R.; Wu, V.C.H. Lowbush wild blueberries have the potential to modify gut microbiota and xenobiotic metabolism in the rat colon. PLoS ONE 2013, 8, e67497. [CrossRef]

84. Faria, A.; Fernandes, I.; Norberto, S.; Mateus, N.; Calhau, C. Interplay between anthocyanins and gut microbiota. J. Agric. Food Chem. 2014, 62, 6898-6902. [CrossRef]

85. Healey, G.R.; Murphy, R.; Brough, L.; Butts, C.A.; Coad, J. Interindividual variability in gut microbiota and host response to dietary interventions. Nutr. Rev. 2017, 75, 1059-1080. [CrossRef]

(C) 2019 by the authors. Licensee MDPI, Basel, Switzerland. This article is an open access article distributed under the terms and conditions of the Creative Commons Attribution (CC BY) license (http://creativecommons.org/licenses/by/4.0/). 